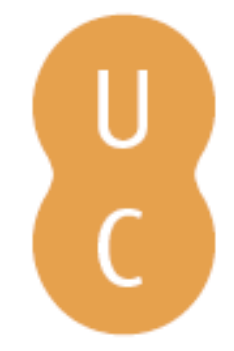

\title{
pommalina
}

\section{Education and communication on radiological protection: the potential value of information technologies to improve professional skills}

\author{
Autor(es): $\quad$ Levy, D. S.; Sordi, G. M. A. A. \\ Publicado por: Imprensa da Universidade de Coimbra \\ URL \\ persistente: URI:http://hdl.handle.net/10316.2/44474 \\ DOI: $\quad$ DOI:https://doi.org/10.14195/978-989-26-1602-5_31 \\ Accessed : $\quad$ 26-Apr-2023 09:36:06
}

A navegação consulta e descarregamento dos títulos inseridos nas Bibliotecas Digitais UC Digitalis, UC Pombalina e UC Impactum, pressupõem a aceitação plena e sem reservas dos Termos e Condições de Uso destas Bibliotecas Digitais, disponíveis em https://digitalis.uc.pt/pt-pt/termos.

Conforme exposto nos referidos Termos e Condições de Uso, o descarregamento de títulos de acesso restrito requer uma licença válida de autorização devendo o utilizador aceder ao(s) documento(s) a partir de um endereço de IP da instituição detentora da supramencionada licença.

Ao utilizador é apenas permitido o descarregamento para uso pessoal, pelo que o emprego do(s) título(s) descarregado(s) para outro fim, designadamente comercial, carece de autorização do respetivo autor ou editor da obra.

Na medida em que todas as obras da UC Digitalis se encontram protegidas pelo Código do Direito de Autor e Direitos Conexos e demais legislação aplicável, toda a cópia, parcial ou total, deste documento, nos casos em que é legalmente admitida, deverá conter ou fazer-se acompanhar por este aviso.

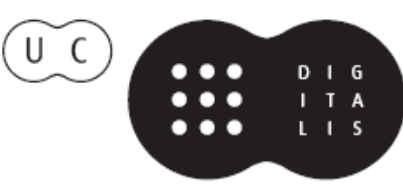




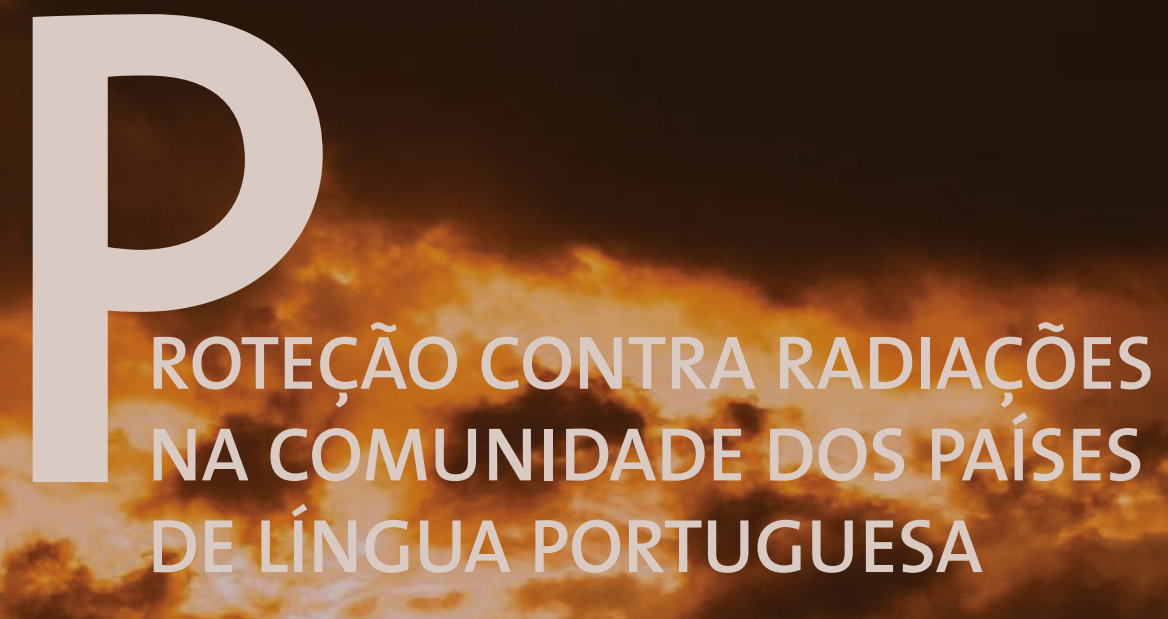

\section{ROTEÇÃO CONTRA RADIAÇÕES NA COMUNIDADE DOS PAÍSES DELINNGUA PORTUGUESA}

Luis Neves (coord.)

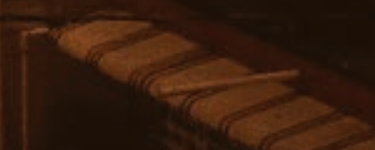


EDUCATION AND COMMUNICATION ON RADIOLOGICAL PROTECTION: THE POTENTIAL VALUE OF INFORMATION TECHNOLOGIES TO IMPROVE PROFESSIONAL SKILLS

EDUCAÇÃo E COMUNICAÇÃO EM PROTEÇÃo RADIOLÓGICA: O POTENCIAL DAS TECNOLOGIAS DA INFORMAÇÃO PARA O APRIMORAMENTO DE COMPETENCIAS PROFISSIONAIS

D. S. LEVY - denise@omiccron.com.br (Instituto de Pesquisas Energéticas e Nucleares - IPEN-CNEN/SP)

G. M. A. A. SORDI - gmsordi@ipen.br (Instituto de Pesquisas Energéticas e Nucleares - IPEN-CNEN/SP)

KEYWORDS: radiological protection, optimization, monitoring, Information Technologies.

ABSTRACT: For operational control of exposures to ionizing radiation in any workplace, the International Commission on Radiation Protection (ICRP) recommends establishing a program of operational radiation protection, proportional to the risk, to ensure the effective management of all necessary measures to satisfy the principle of optimization. This project focus on the potential value of Information and Communication Technologies (ICTs) to enhance education and communication on Radiological Protection throughout Brazil. The content includes optimization programs and monitoring policy and techniques, interrelating 
information currently scattered in several documents, providing Brazilian facilities a complete repository for consultation and information. The content also brings new approaches from some recommendations, presenting some initiatives towards protection and safety. The growing impact of ICTs shall contribute greatly to provide information where it is needed, stimulating development in this large country where it is a huge challenge to ensure access to information to as many people as possible, minimizing costs and optimizing results.

PALAVRAS-CHAVE: proteção radiológica, otimização, monitoramento, Tecnologias da Informação.

RESUMO: Para o controle operacional das exposições à radiação ionizante no local de trabalho, a Comissão Internacional de Proteção Radiológica (CIPR) recomenda um programa de proteção radiológica operacional, proporcional ao grau de risco, para garantir o gerenciamento efetivo das medidas necessárias para se satisfazer o princípio da otimização. O presente trabalho tem como premissa o potencial das Tecnologias da Informação e Comunicação (TIC) como ferramenta para a comunicação e disseminação do conhecimento em Proteção Radiológica. O trabalho inclui a informatização da filosofia e técnica do monitoramento e sua otimização, unificando e inter-relacionando informações advindas de diversas publicações nacionais e internacionais, oferecendo às instalações radiativas um veículo completo para informação e pesquisa, que permite dimensionar os esforços de otimização tornando-os eficazes e justificados. O sistema oferece ainda tópicos de discussões visando ampliar o repertório dos profissionais do campo da proteção radiológica e suscitando novas reflexões a favor da segurança. Acreditamos que o potencial das TIC contribuirá largamente para a disseminação 
da informação para as instalações radiativas, estimulando o desenvolvimento neste país de grandes extensões territoriais, onde permanece um desafio oferecer o acesso à informação ao maior número de pessoas possível, minimizando custos e maximizando resultados.

\section{INTRODUCTION}

A monitoring program for the purposes of radiological protection should demonstrate an adequate protection degree and prove that working conditions remain appropriate as time goes by. For operational control of exposures to ionizing radiation in any workplace, the International Commission on Radiation Protection (ICRP) recommends establishing a program of operational radiation protection, proportional to the risk, to ensure the effective management of all necessary measures to satisfy the principle of optimization (ICRP, 1997).

In order to establish a Radiological Protection Plan or a Radiological Emergency Plan, Brazilian facilities should take into account all procedures based on both national and international standards, guidelines and recommendations. This information can be found in several documents published by different organizations over the past decades. International recommendations are given by the International Commission on Radiological Protection (ICRP) and International Atomic Energy Agency (IAEA). In Brazil, national recommendations are defined by the National Commission of Nuclear Energy (CNEN), which is the national government entity, linked to the IAEA and under the Ministry of Science and Technology, that has issued a large amount of standards for radioactive facilities in the country (CNEN, 2011), about programs that are adequate and effective to remain in operation for radiological protection. 
We believe that the use of Information and Communication Technologies (ICTs) for the radiological protection communication shall help greatly the professional that requires such use. Taking advantage of the impact of ICTs in modern Information Society and its institutions this project aims the communication of the radiological protection programs in a single system in order to offer unified programs and interrelated information in Portuguese, providing Brazilian facilities a complete repository for research, consultation and information in a quick, integrated and efficient way. This research focuses on the potential value of Information and Communication Technologies (ICTs) to enhance communication and education on Radiological Protection throughout Brazil, offering conditions for learning and improving professional skills.

\section{METHODOLOGY}

\subsection{Monitoring and optimization procedures}

In order to attend both national standards of CNEN (CNEN, 2011) and the new international recommendations of ICRP (ICRP, 2007) and IAEA (IAEA, 2014) within the scope of this work, the development of this project started from concepts, definitions and theory, aside from the detailed survey of the optimization and monitoring program contents in order to interrelate information, currently scattered in several publications and documents, in a consistent and appropriate manner. The unification of optimization and monitoring programs implies working on a vast and complex content, identifying the most appropriate functional structure in order to develop a project that allows effective access to information and research. Therefore, this research work started from optimization content, including concepts, definitions and theory in addition to the optimization programs, help decision making techniques, information related to protection 
costs, radiation doses and detriment. Also, the content brings interrelated information about the construction of the optimization process, its characteristics, the involvement of stakeholders, the global components to define and implement an ALARA Program, the dose distribution in time and space and collective dose matrix for decision making (ICRP, 1973, 1983, 1990, 2006; IAEA, 2002). Moreover, this web-based system offers simulators for each one of the help decision making techniques recommended by ICRP (ICRP, 1990). The simulators proved to be helpful, specially whether there is a great amount of options and factors to be chosen, such as the decision techniques known as Multi-Attribute Utility Analysis and Multi-Criteria Analysis Outranking. Once the software is fed with appropriate data, the optimal analytical solution can be calculated in just few seconds.

In 2013 our team started the research that comprised several aspects of the monitoring policy and techniques, which includes concepts, definitions and theory about monitoring procedures, integrating and interrelating elements of optimization and monitoring programs. In order to introduce the basic concepts of monitoring, the system presents the criteria used for control of occupational exposures, discussing normal and potential exposures, authority and responsibility, classification of work areas, practical implications and engineering controls, operational procedures, reference levels, types of monitoring and its functions. The system provides detailed information about workplace monitoring (monitoring for external radiation, monitoring for surface contamination and monitoring for air contamination) and individual monitoring (monitoring of external exposure and monitoring of internal exposure and monitoring for skin and clothing), discussing objectives, routine monitoring, task-related monitoring, special monitoring and interpretation of results for each type of monitoring program (ICRP, 1997, 2007; CNEN, 2011; IAEA, 2014). 
Furthermore, in order to help users to increase their understanding about monitoring programs, it was created exclusively for this purpose, an interactive virtual component presenting hypothetical problem-based situations related to workplace monitoring for air contamination and workplace monitoring for external radiation.

Moreover, the content of monitoring programs involves not only the collection and interrelationship of existing information in the publications, but also new approaches from some recommendations, presenting some initiatives towards safety.

\subsection{New approaches from some international recommendations}

This research work brings the possibility of discussions of new approaches from some recommendations, proposing appropriate actions as a possibility to be incorporated into labor practice. In this sense, the two contents researched and discussed are: the possibility of an auditor monitoring and some discussions on potential exposures. An auditing program applied to task related monitoring permits to evaluate whether criteria and actions previously established by Radiological Protection Service are effectively implemented and remain appropriate as time goes by. The results of auditing procedures help to detect deficiencies in the process, enabling conclusions and recommendations, avoiding possible triggers of undue exposures. Through systematic examinations of activities in each type of monitoring, auditing attempt to ensure the process, supporting the employee in performing task-related monitoring and support the facility that choose responsible actions towards safety.

Furthermore, regarding potential exposures, only two publications of ICRP develop expressively the issue (ICRP, 1993, 1997). Nevertheless, some recommendations are not developed, making it difficult to discuss information in a complete and clear way, even from the original publications. Even though some ICRP publications 
recommend that the potential exposure should be treated together with normal exposure, in its publication 76 (ICRP, 1997), ICRP assumes that in most situations this is not possible, since normal occupational exposure is based on dose limits, while in potential exposure there should be considered the highest doses of the scenario. According to ICRP Publication 76, in its section 62:

"The methods for optimization of radiation protection range from simple common sense to complex quantitative techniques (see Publications 37 and 55; ICRP 1983, 1989). Optimization of protection against potential exposure is still largely unresolved, particularly when probabilities are low and consequences are big (NEA / OECD, 1995). Although the present report conceptually equates risks from normal and potential exposures, simultaneous, formal optimization of protection against both types of exposure would be difficult. However, the use of devices for protection against potential exposures, as outlined here, already includes an element of optimization. Also, the reference risk used in this report corresponds to the risk associated with the highest occupational doses in an optimized operation, rather than to the risk associated with a dose at the occupational dose limit. Still, optimal protection against potential exposures is not necessary achieved at the same level of risk as optimal protection against normal exposures. This is because the costs of reducing risks from normal exposures may be quite different." (ICRP, 1997; OCDE, 1995)

Although this publication recognizes that these two issues should be treated separately, it does not provide specific recommendations. As a matter of fact, there is still lack of knowledge of failure probabilities, which currently constitutes a broad research field in radiological protection. This research proposes the development of fault trees, suggesting paths to help to quantify probabilistically 
the occurrence of potential exposures, as well as probabilities to reach a certain level of dose. The scenarios proposed bring the interrelationship of 3 different publications:

- ICRP 76: using the following examples: fault tree analysis of the radiotherapy device, fault tree analysis of a modern irradiator and fault tree analysis of an accelerator for isotope production. (ICRP, 1997)

- AIEA 102: regarding the positive tree, published by in 1990, which is considered the more generic and complete tree for an appropriate program of radiation protection. (IAEA, 1990)

- AIEA TECDOC 430: bringing the requirements and symbols for the correct development of a fault tree. (IAEA, 1987)

The scenarios constructions intend to be complete and general, so that they can be extended and applied by similarity to any radioactive facility according to its specific situation. Furthermore, in the site, users receive all relevant information to build correct and complete event or fault trees for radiological protection programs, according to AIEA TECDOC 430 recommendations. We understand that the construction of more complete trees shall help facilities to anticipate possibilities and events that contribute to undue exposures which derive from sequences that could be probabilistically predicted.

The discussions concerning the audit function of monitoring and potential exposures, bring new possibilities, inspiring new attitudes towards protection and safety for professionals involved in radiological protection issues.

\section{RESULTS AND DISCUSSION}

Information and Communication Technology (ICT) is growing in Brazil and worldwide. The servers processing power added to 
the technology of relational databases allow to integrate information from different sources, enabling complex queries with reduced response time. The pioneer project UNIPRORAD (Levy, 2012) counts on modern educational technology concepts, providing Brazilian radioactive facilities a complete repository for research, consultation and information in a quick, integrated and efficient way.

The WEB platform tools and functionalities has been developed according to our target public needs, regarding the results provided by our pilot project first implemented in a web environment in March 2012. Google Analytics was used to the investigation of the usage profile. According to its monitoring reports, between 26/05/2012 and 26/06/2012 the site UNIPRORAD counted on 79 visits and 1.353 page views from 43 users, among which 50,63\% were returning visitors (Figure 1). Since then the number of visitors increases month after month, confirming that professionals related to radiological protection make use of this web-based tool for consultation and information. According to Google Analytics reports, between 09/06/2015 and $08 / 07 / 2015$ the website UNIPRORAD received 202 visitors, among them $51,29 \%$ returning visitors, which registered a total of 4.647views (Figure 2). 


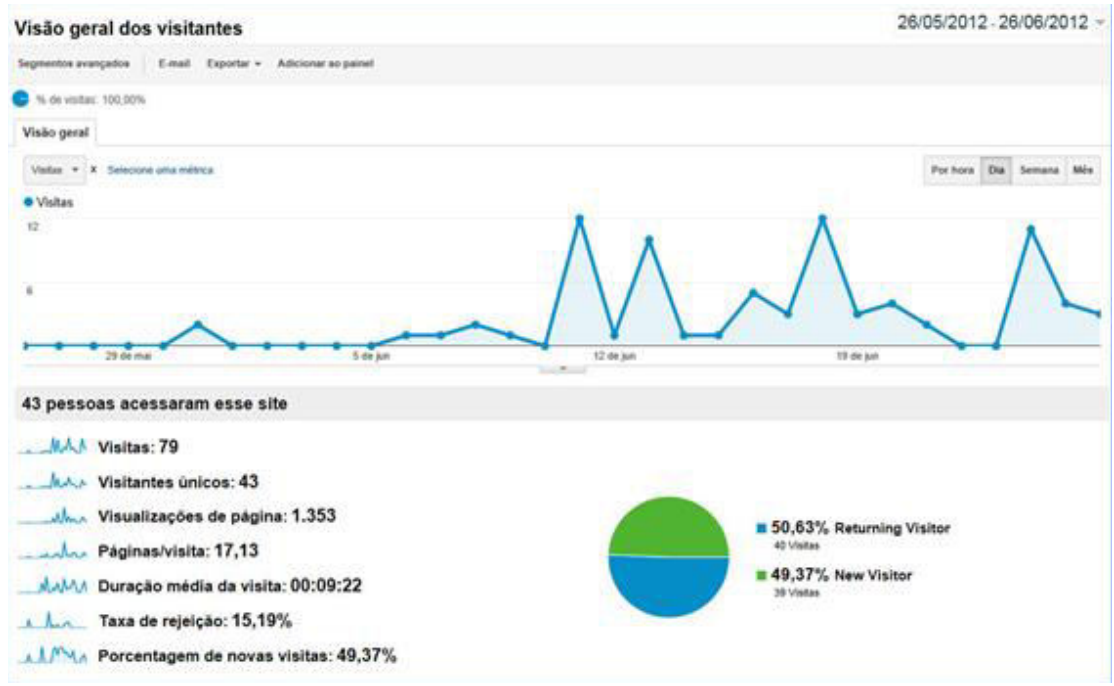

Figure 1. Usage profile between 26/05/2012 and 26/06/2012

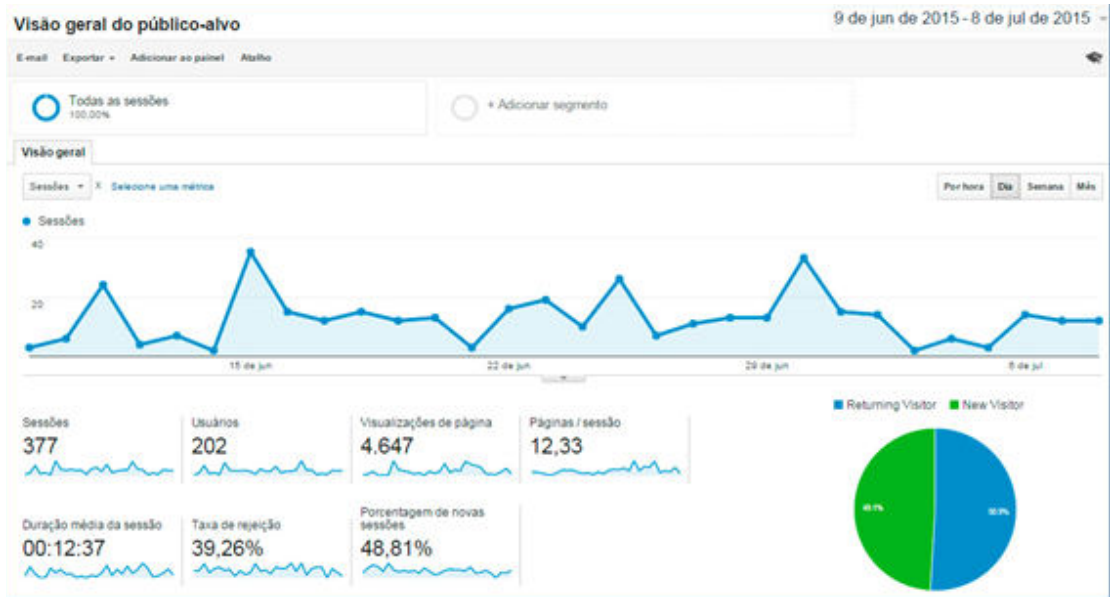

Figure 2. Usage profile between 09/06/2015 and 08/07/2015

Still, Google Analytics reports information about user's operational systems profiles, services providers and screen resolutions, providing fundamental information for strategical planning of the evolution of this Project, as the WEB platform tools and functionalities must be 
developed according to our target public needs, regarding new possibilities of media, like mobile access, feeds of content and information sharing. Moreover, taking into account this is a pioneer project with the prospect of long-term use, our challenge involves the combination of multiple computer technologies that allows a robust, effective, and flexible system, which can be easily adapted according to future technological innovations.

Taking into account that ICTs proved to be a useful tool this research project should be extended to other fields of radiological protection, according to the positive Tree, published by IAEA (IAEA, $1990)$ in 1990 , the more generic and complete tree for an appropriate program of radiation protection. It is out target to complete the system including other relevant issues, such as safe transport of radioactive materials, emergency response and radioactive waste management and decommissioning, among others.

\section{CONCLUSION}

Making use of the Internet, wireless networks, cell phones and other digital media, ICTs provide a huge array of new communication possibilities, spreading information from anywhere in the world to geographically distant regions at low costs and high quality communication. Moreover, considering radiation protection field, ICTs present unprecedented opportunities to education and information, for it enables researchers to produce, adapt and apply great amount of specific knowledge, improving the quality of communication. We believe in the growing potential of ICTs to disseminate information throughout Brazil, contributing to deliver information where it is needed and stimulating development to all aspects of the Brazilian society. An unprecedented opportunity to offer conditions for learning and improving professional and personal skills in this large country 
where it is still a strong challenge to ensure access to information to as many people as possible, minimizing costs and optimizing results. This pioneer project shell help greatly both radioactive facilities and researchers, and it is our target to make it an international reference for Portuguese Spoken countries.

\section{References}

International Commission on Radiological Protection. (1997a) General Principles for the Radiation Protection of Workers, publication ICRP 75. Vienna.

Comissão Nacional De Energia Nuclear. (2011) NN 3.01: Diretrizes Básicas de Proteção Radiológica. Rio de Janeiro.

International Commission on Radiological Protection. (2007) The 2007 Recommendations of the International Commission on Radiological Protection, publication ICRP 103. Vienna.

International Atomic Energy Agency. (2014) Safety Standards for Protecting people and the environment - Radiation protection and safety of radiation sources: international basic safety Standards, General Safety Requirements - Part 3. Vienna.

International Commission on Radiological Protection. (1973) Implications of Commission Recommendations That Dosis Be Kept as Low as Readily Achievable, publication ICRP 22. Vienna.

International Commission on Radiological Protection. (1983) Cost-Benefit Analysis in the Optimization of Radiation Protection, publication ICRP 37 Ann. ICRP 10 (2-3). Vienna.

International Commission on Radiological Protection. (1990) Optimization and Decision-Making in Radiological Protection, publication ICRP 55 Ann. ICRP 20 (1). Vienna.

International Commission on Radiological Protection. (2006) The optimization of the Radiological Protection: Broadening the Process, publication ICRP 101b, Ann. ICRP 36 (3). Vienna.

International Atomic Energy Agency. (2002) The optimization of the Radiation Protection in the Control of Occupational Exposure, Safety Report Series n. 21. Vienna.

International Commission on Radiological Protection. (1993) Protection from Potential Exposure - A Conceptual Framework, publication ICRP 64. Vienna.

International Commission on Radiological Protection. (1997b) Protection from Potential Exposures - Application to Selected Radiation Sources, publication ICRP 76 Ann. ICRP 27 (2). Vienna.

OCDE, NEA. (1995) The meaning and application of the concept of potential exposure, CRPPH/CSNI/CNRA/RWMC Expert Group. Paris. 
International Atomic Energy Agency. (1990) Recommendation for the Safe Use and Regulation of the Radiation Source in Industry, Medicine and Teaching. Safety Series n. 102. Vienna.

International Atomic Energy Agency. (1987) Procedures for the systematic appraisal of operational radiation protection programs, publication IAEA TECDOC 430 . Vienna.

Levy, D. S. (2012) UNIPRORAD Unificação dos Programas de Proteção Radiológica. www.uniprorad.com.br last access: 15/02/2017 